Gandy, Robert, Harrison, Patricia and

Gold, Jeff ORCID: https://orcid.org/0000-0003-0289-6712 (2018) Criticality of Detailed Staff Turnover Measurement. Benchmarking: an international journal, 25 (8). pp. 2950-2967.

Downloaded from: http://ray.yorksj.ac.uk/id/eprint/2883/

The version presented here may differ from the published version or version of record. If you intend to cite from the work you are advised to consult the publisher's version: https://www.emeraldinsight.com/doi/pdfplus/10.1108/BIJ-11-2017-0302

Research at York St John (RaY) is an institutional repository. It supports the principles of open access by making the research outputs of the University available in digital form. Copyright of the items stored in RaY reside with the authors and/or other copyright owners. Users may access full text items free of charge, and may download a copy for private study or non-commercial research. For further reuse terms, see licence terms governing individual outputs. Institutional Repository Policy Statement

\title{
RaY
}

Research at the University of York St John

For more information please contact RaY at ray@yorksj.ac.uk 


\section{Criticality of Detailed Staff Turnover Measurement}

\section{Introduction}

Staff turnover is key workforce measure for all organisations (Gates 2004; Allen et al., 2010), potentially providing valuable insights into what is happening within a workforce, generally retrospectively, by examining why staff that have left (Veleso et al., 2014). However, there is often 'scant attention given to turnover' (Lawrence et al., 2013, p.513) possibly because it is a concept taken for granted. Nevertheless since it involves comparatively straightforward formulae with many published, high-level benchmark analyses, it could be considered to reveal savings or sources for improved efficiency. Research has shown that high staff turnover can be harmful for an organisation's performance (Glebbeek and Bax, 2004), especially among core staff (Siebert and Zubanov, 2009). Organisations can examine staff turnover when seeking reductions through natural wastage ((Hancock et al., 2013; Sutherland, 1998), rather than compulsory redundancies. For example, a major multinational company based in the United Kingdom (UK) with an annual natural wastage rate of $20 \%$, found that one small unit with a harsh environment had such a high staff turnover that it had skewed this figure; when the unit was excluded the natural wastage for the rest of the company was only c.5\% (Gandy, 2009). Staff turnover can increasingly be seen as a feature of what is referred to as People Analytics that enables a more complex understanding of the key patterns of human resource (HR) data, allowing better decisions relating to workforce planning (de Romrée et al., 2016).

The purpose of the research presented in this paper is to challenge the largely predominant use of benchmarking headline staff turnover rates by investigating the degree to which such 
rates can mask internal variations in turnover in large organisations. It does this by analysing the actual situation in one such organisation in Higher Education (HE) in the UK. Accordingly the research looks at variations between university departments and between the different gender and age groups, the latter being particularly important given the evolving age-diverse workforce of the sector. It uses data from a large post-1992 HE institution in the UK, with over 2,000 staff (Armstrong, 2008). We begin by considering the issue of staff turnover in the context of $\mathrm{HE}$ and the value of benchmarking. We then consider the research that we conducted in a large HE organisation followed by a discussion of the results before concluding on the importance of a complex approach to staff turnover to enable appropriate responses. 


\section{Staff Turnover in Higher Education}

The measurement of staff turnover is one of number of workforce planning techniques to provide data relating to flow of people in organisations but also as a way to understand workforce problems. The loss of talented staff in particular has important cost implications so an understanding of turnover can help the formulation of responses to staff retention (Bratton and Gold, 2017).

Research exists about staff turnover and factors influencing why people leave their jobs (Cardy and Lengnick-Hall, 2011), and factors influencing people to remain with a company (Cotton and Tuttle, 1986), particularly where there are recruitment difficulties and escalating skills shortages (CIPD, 2015a). However, there is little in-depth quantitative research into staff turnover, and the degree to which headline organisational rates can mask internal variations. An organisation's understanding of its workforce is vital and can engender benefits at both an operational and strategic level (Hancock et al., 2013; Raju et al., 2015). The approach, findings and lessons for staff management that are set out, are therefore relevant to many, if not most large organisations in the private and public sector, both in the UK and internationally.

\subsection{Workforce in Universities}

Universities are increasingly competing in a global market (Marginson, 2013), with management styles and approaches being adopted from the private and industrial sectors. In the UK this is reflected in competition for academic staff with strong research skills (Mahroum, 1999; Ackers and Gill, 2005) and the application of performance indicators such as number of PhD-educated academic staff (Breakwell and Tytherleigh, 2010). In the UK HE academic staff are more weighted towards older age groups, with $21 \%$ aged 55 years and over, and only 25\% aged under 35 years in 2008/09 (HESA, 2010); but since April 2011, 
employers cannot issue retirement notices to their employees (Age UK, 2015). Younger employees exhibit very different attitudes to the length of time they will stay in a job: those born between 1977-1994, viz. Generation Y or 'Millennials' (Schroer, 2015), are more likely to be unsatisfied with their work and report higher levels of turnover, compared to other generations (Brown et al., 2015). In addition, the vast majority of Generation Y employees plan to stay less than five years with one employer, and more than a third (37\%) plan to stay no more than two years (London Business School, 2015). As Generation Y employees are likely to incrementally increase as a proportion of UK workforces, including HE, it is probable that staff turnover rates will also increase. Therefore, it is critical to know who is staying and leaving (Cardy and Lengnick-Hall, 2011), because it can be both costly and problematic to recruit and train new talent (Groysberg, 2010; Collings, 2015); CIPD (2015a, p.27) reported considerable variance in the spend of organisations on recruitment, quoting median costs of $£ 7,250$ for senior positions and $£ 2,000$ for other employees. In the USA, the estimated recruitment and start-up costs of universities replacing science faculty members varied between $\$ 300,000$ and $\$ 700,000$ (Ehrenberg et al., 2006).

A related issue is that many younger academics start their careers with fixed-term contract, research posts; acquiring permanent academic posts after a period of time, many moves or multiple job holding (Metcalf et al., 2005). Given the increasing focus on research in many universities (Ref2020 Consulting, 2015), this situation suggests that HE institutions' staff turnover patterns will be influenced by the number of departments with significant research profiles.

\subsection{Benchmarking}

Universities routinely benchmark staff turnover (UNESCO, 1998), but by definition, the vast majority will not be outliers. Unfortunately, concentration on headline figures can mislead, 
because net turnover can mask widely varying situations: the number of new staff and staff lost can both be large or both be small and have the same difference between them. For example, a net turnover rate of minus $5 \%$ can be the result of a $2 \%$ turnover rate for recruited staff and a 7\% turnover rate for staff lost (see formulae below); it can also be the result of a $23 \%$ turnover rate for recruited staff and a $28 \%$ turnover rate for staff lost. Such scenarios have different implications for HR management; not least is that the latter involves far more recruitment resources than the former. It is contended that there is a genuine risk that a university will consider being a non-outlier as 'acceptable' and not take related matters further, when detailed scrutiny of turnover below institution level might point to situations that require attention.

There is evidence of HE institutions working collaboratively with each other to improve overall performance although this tended to be in an informal way. It was primarily from the early 1990s that the development of benchmarking in HE enabled formalised comparisons. The main reasons included: greater international competitiveness; the development of an interest in enhancing quality; and the rapid growth of information technology which made data collection and management possible (UNESCO, 1998). The methodology of benchmarking with its conceptual emphasis on openness of analysis, organisational learning, and an examination of processes, rather than a narrow focus on input or output data, encouraged some commentators to be optimistic about its application in universities: arguing that such a methodology fits a university culture more comfortably than other forms of change management (UNESCO, 1998).

Hence, HE institutions have adopted a benchmarking approach to support HR and other management functions. Several professional, private and public organisations benchmark staff 
turnover in HE in the UK, using university-wide data; namely, The Chartered Institute of Personnel and Development (CIPD) (2016), DLA Piper (2015), the Higher Education Statistical Agency (HESA) (2014), the Universities and Colleges Employers Association (UCEA) (2014), and the Workforce Employment Relations Study (WERS) (2013). In addition, to support HE institutions, HESA created the Higher Education Information Database for Institutions (HEIDI) (2015); a data explorer which creates pre-structured analyses and reports of HESA data. Staff turnover is only one of many HR-related topics analysed by each of the aforementioned.

Consequently it was necessary to examine each of these as part of the research, to establish the opportunities for universities to benchmark staff turnover and stability below institution level, across the HE sector. This necessarily included the benchmarking data collected and how staff turnover was calculated, to see if there were differences in data, definitions or analyses, and whether they could support (full) analyses below institution level.

\section{Methods}

The research involved a large post-1992 UK HE institution (Armstrong, 2008), with five academic faculties and three support/ managerial divisions (excluding 'Other'). It covered the full academic year immediately preceding the Resource Excellence Framework (REF) (2015), viz. 1st August 2012 to 31st July 2013, in part because it was suspected (some) universities recruited staff to specifically contribute to their REF score, thereby increasing their allocation of related resources.

\subsection{Data}

The university studied provided anonymous staffing data, as follows: Anonymous identifier; Age; Gender; Start Date; Leaving Date; Reason for Leaving; Disability Status; Ethnic Origin; 
Nationality; Grade Name; Job Name; Department; Location; Full Time Equivalent (FTE);

Employment Category; and, Nature of Fixed Term. The categories assigned to each data are not set out here, but are evident from the resulting analyses. They reflected the actual data available on the university database.

For some data, categories were merged for the analytical purposes. FTE was translated into hours worked per week (based on a 35-hour week) in four categories: Under 16 hours; 16 hours and up to 24 hours; 24 hours and up to 30 hours; and 30 hours and over. These categories were chosen because: people need to work 16 hours and over, or 24 hour and over, to gain certain government working tax credits (Welfare Rights on the Net, 2015), and WERS (2013) differentiates part-time staff as working fewer than 30 hours per week and full-time as 30 hours or more per week.

Ages were aggregated into 10-year groups starting with age 20 years (with 'Under 20 years' and '60 years and over' at either end of the range). Separate analyses were undertaken for staff aged '35 years and under' for Generation Y.

There were 13 different types of contract, but nearly all staff had either a permanent or a fixed-term contract. Therefore all other forms of contract mentioning 'permanent' were aggregated with the former and all other forms mentioning 'fixed-term' were aggregated with the latter for analytical purposes. This left one other category, viz. Joint Contract. For confidentiality purposes faculties are anonymised using broad descriptors, e.g. 'An Arts Faculty', with their constituent departments named 'An Arts Faculty: Dept A.1', etc. The same applies for management divisions. 


\subsection{Measurement of Turnover}

Staff turnover rate is defined as the number of employees who leave a company during a specified time period divided by the average total number of employees over that same time period (Department for Work and Pensions and ACAS, 2014). Therefore it measures specific changes in the sizes of cohorts of staff. The data required can be very simple and readily available within any organisation. The (minimum) data required is:

S - Number of staff at start of period

L - Number of staff lost/leaving during period

$\mathrm{N}$ - Number of new staff starting during period

F - Number of staff at finish of period

The turnover rate relating to lost staff is calculated as follows:

Lost Staff as Percentage of Average Numbers $=(2 \mathrm{Lx} 100) /(\mathrm{S}+\mathrm{F})$

The corresponding turnover rate for recruited staff is:

New Staff as Percentage of Average Numbers $=(2 \mathrm{Nx} 100) /(\mathrm{S}+\mathrm{F})$

Therefore, the net turnover rate calculation is: $(2 \mathrm{x}(\mathrm{N}-\mathrm{L}) \mathrm{x} 100) /(\mathrm{S}+\mathrm{F})$

Any staff that both started and left university employment during the period covered, were counted against both 'lost staff' and 'new staff'. The focus was on all staff starting or leaving the university, irrespective of their reason for leaving (i.e. it included reasons other than 'voluntary', such as redundancy), because it was important to understand the full picture. Casual staff, management consultants, and similar were excluded.

The regularly used measure the 'Percentage Stability Index' was also calculated and quoted. This reflects how experienced employees are being retained, and is calculated as the number of workers with one year's service (or more), divided by number of workers employed one year ago, multiplied by ten (Department for Work and Pensions and ACAS, 2014). 


\subsection{Constraints}

The data relate to individuals employed by the university and represent 'headcounts', rather than FTEs. Also, the Measurement of Turnover formulae (above) take the 'average number of staff' as the mean of the number of staff at the start and end of the period, viz. $(\mathrm{S}+\mathrm{F}) / 2$, which is a simple, straightforward and commonly used calculation. Furthermore, no data available was on the destination of staff that left voluntarily and their reasons for leaving. Historically, the university commissioned external consultancies to undertake exit surveys of such leavers, but responses were too poor for useful analysis.

\subsection{Presentation of Turnover Rates}

A diagrammatical approach was included; using the scattergram-related inverted Nomogramma di Gandy (NdiG), which has been used to demonstrate turnover for international trade, populations and staff. It requires minimum data, and shows many data on one diagram, acting as an exploratory data analysis tool for considering problematical issues (Gandy, 2009).

The $\mathrm{X}$ axis is 'Lost Staff as Percentage of Average Numbers', (1) above, and the Y axis is 'New Staff as Percentage of Average Numbers', (2) above. Accordingly, a company/ organisation might be considered 'self sufficient' or 'self contained' if it has not gained or lost staff. In such circumstances, the inverted $N d i G$ value would be $(0,0)$, and the further away from this point, the greater the turnover. This attribution to the axes means organisations with expanding staff appear above the $45^{\circ}$ diagonal, whilst those contracting appear below. The associated tables collate data into meaningful categories: 'Staff at 1st August 2012'; 'Leavers'; 'New Staff'; and 'Staff at 31st July 2013'. 


\section{Results}

Table 1 sets out the above data and indices for age, gender, disability, ethnic group, type of contract, weekly hours and type of staff, with the related patterns shown in Figure 1.

\section{Insert "Table 1 - Staff Turnover Statistics for Key Staff Characteristics}

(01/08/2012-31/07/2013)" near here

\section{Insert "Figure 1 - Turnover Patterns for Categories of Staff \& Staff Characteristics" near here}

Total staff decreased from 2,346 to 2,277 over the period. This $3 \%$ reduction was the net effect of $10 \%$ of staff leaving with $7 \%$ replacement. There were staff reductions in each agesex group except the under 20 s, and males aged $20-39$ years. It is noted that $57 \%$ of female leavers were under 40 years of age, compared to $43 \%$ for males.

The age profile of academic staff was slightly older than non-academic staff, with mean ages of just over 47 years and 45 years respectively; the mean for males was marginally greater than for females in both cases. Research staff had a mean age of just over 38 years, but with a mean of 41 years for males and 35 years for females. For staff aged 60 years and over 124 (56\%) were full-time staff, of which males accounted for $76(61 \%)$. By contrast females accounted for $64(65 \%)$ of the 98 part-time staff.

The greatest turnover was in the younger age groups, particularly those aged 20-29 years. It can be seen that the limited differences in net turnover rate between Generation Y and other staff masked large differences between the graphical indicator values, with Generation Y being outliers for both males and females. The net turnover rate for staff classified as disabled was positive, involving low levels of turnover. This compares with negative turnover for nondisabled staff. The differences in turnover patterns for staff with permanent and fixed-term contracts were marked, but the latter only accounted for $8.5 \%$ of the workforce. 
Classifying staff working 30 hours and over per week as 'full-time' (WERS, 2013) meant just over three-quarters of all staff were 'full-time'. The greatest turnover involved part-time staff working less than 16 hours per week, despite their net turnover being similar to the university mean. The greatest negative net turnover was for staff working 24-30 hours.

The university increased its academic staff, balanced by reductions in administration and research. The low turnover rates for academic staff compare with high rates for research staff, arguably representing fairly stable and more volatile situations respectively. There were 90 research staff with fixed-term contracts at the beginning of the year, and 67 at the end. So although they accounted for only $3.8 \%$ of the total staff at the beginning of the year, they accounted for $18.5 \%$ of the staff leaving and $12.2 \%$ of the staff starting. Part-time research staff on fixed-term contracts yielded substantial turnover, with a net turnover of -74.3; accounting for $29.7 \%$ of part-time staff that left and $13.0 \%$ of such staff that started. The varying patterns within and between faculties/ divisions are evident from Table 2 and Figure 2, which serves to highlight the importance of drilling down into the organisational structure. Turnover rates for the support/ managerial divisions were all lower than those for the academic faculties bar one, with all those above the university mean attributable to faculties. For individual academic departments it became evident that the five with the highest patterns of turnover, viz. Science Faculty Departments S.1, S.3, and S.5, and Technology Faculty Departments T.1 and T.6, also had high percentages of fixed-term contract and/ or research staff.

\section{Insert "Table 2 - Staff Turnover Statistics for Faculties and Divisions (01/08/2012-31/07/2013)" near here Insert "Figure 2 - Turnover Patterns for Faculties and Divisions" near here} There was a significant positive correlation between net turnover and the percentage stability index ( $\mathrm{p}<0.01, \mathrm{r}=0.52)$, which may be expected because faculties/ divisions losing most staff 
would have lower levels of stability compared to those with (large) positive turnover where most original staff will be retained.

\subsection{Benchmarking Sources}

Critical scrutiny of the five named organisations' surveys that benchmark staff turnover in HE highlighted variations in the data, staff categories and formulae used (see Table 3). Their coverage of HR topics and HE institutions varies, as does the frequency of surveys. They use different definitions of staff turnover formulae, with some concentrating on voluntary leavers and some including involuntary leavers (e.g. staff redundancies). Some accept 'best estimates' if exact data is not available. Presentational details also vary, e.g. the percentage stability index is not always calculated. Importantly, none measure staff turnover for both starters and leavers.

HEIDI operates at a cost centre level for 'Total Staff' data, and any institution can be chosen. It involves FTEs and full-person equivalents (HESA, 2015), neither of which is the same as the headcount data used in the research. Cost centres are not the same as schools and, different universities call their departments by different names. Also, for confidentiality and data protection reasons, details of starters and leavers are only available at an institutional level, and the small numbers involved mean no related demographic data analyses are available. Unfortunately, this means that HEIDI cannot be used to benchmark the data used in the research analyses.

\section{Insert "Table 3 - Summary of how existing Benchmarking sources deal with Staff Turnover" near here}




\section{Discussion}

Although the results relate to a large post-1992 UK HE institution, some patterns and issues may apply to most HE institutions and large organisations, albeit with different emphases reflecting their nature, organisation and size. Therefore lessons from this research have general relevance.

\subsection{Benchmarking Sources}

The review of existing benchmarking sources (see Table 3) highlighted that there are variations between how different universities measure their staff turnover, according to the benchmarking agency used. It can be argued that none of the formulae and data used are incorrect because there is no universally specified single definition of staff turnover. Of course there will be consistency between the universities using the same agency, but where comparisons might be made between universities that use different agencies there is a risk that like is not being compared with like, which could lead to erroneous inferences. Although some of the variations are comparatively small, this is more likely to happen where they are more marked, e.g. where one source includes involuntary leavers and another does not.

\subsection{Justification for detailed analysis}

The review of existing benchmarking sources also demonstrates that opportunities for universities to benchmark staff turnover and stability across the HE sector below institution level are negligible. But detailed analysis is essential, as concentrating solely on benchmarking outputs risks key inter-departmental variations being missed. Hence, a complementary approach is required: external macro-comparisons with other universities at headline institutional level; and internal micro-comparisons between faculties/ departments and divisions (allowing for variations in data definitions and calculations).

Table 1 and Table 2 demonstrate wide variations in turnover patterns between different faculties/ departments and divisions within a university, and between different categories of 
staff; with the wide differences in $\mathrm{X}$ and $\mathrm{Y}$ values for Generation $\mathrm{Y}$ and other staff, for both sexes, being perhaps the best example. Hancock et al. (2013) highlighted both positive consequences (e.g. reduced compensation costs) and negative consequences (e.g. impact on cost and organisational performance) of high staff turnover. They concluded that on balance the negative effects outweighed the positive effects. Therefore a transparent, detailed understanding of staff turnover is essential.

Turnover needs to be calculated for both new staff and leavers because these can vary considerably, and simply focusing on net turnover can mask important differential patterns. The inverted NdiG enables initial exploratory data analysis which sets out such variations in one presentation and allows attention to be drawn immediately to any outliers; with expansion and contraction respectively reflected by being above or below the diagonal (Gandy, 2009). However, the diagram does not reveal the causes for such variations; it simply points to where more detailed analysis might be required, which could involve both soft and hard data, some of which was not part of the basic dataset used in this research. This could include exit surveys of leavers if there is confidence in the response.

The issues worthy of more detailed investigation identified by this research are potentially generic for universities. They include the varying patterns between age and sex groups for the different types of staff, and the relationship between fixed-term contracts and research posts. Each has implications for recruitment, retention and staff management. Moreover, there is the need to identify potential areas of concern in respect of organisational health; for example, very high turnover in a department might reflect dissatisfaction with the management style and practices. Conversely, very low turnover may reflect a department that has grown stale and needs fresh blood. Such diagnoses would not be apparent solely from staff turnover 
figures; the figures would simply act as pointers and prompts for where further enquiry might be required.

\subsection{Age-diverse issues}

The results showed that there are diverse staff turnover dynamics taking place, particularly across the different age groups, with some gender factors in play. The highest turnover was in the younger age groups, which Generation Y straddle, and the number of women leaving exceeded the number of men for both the 20-29 and 30-39 years age groups, although women were in the majority for both age groups. To a certain degree it is to be expected that there may be greater staff turnover in younger staff as they move jobs as part of their career progression, change career entirely or leave to raise a family. However, such reasons for leaving were not known for many: 106 (45.5\%) were recorded as 'Resignation'.

Metcalf et al. (2005) found that $15 \%$ of permanent academic staff thought their moving to another UK university in the next year was 'quite likely', 'very likely' or 'definitely'; 9\% of permanent staff and $24 \%$ of fixed-term contract staff anticipating leaving. A similar proportion of leavers left the HE sector as remained, and business-related areas were particularly vulnerable to losing staff to other sectors. Of course, Generation Y people were only just entering the workplace at the time of Metcalf et al. 's research, i.e. 2004. Therefore questions arise: whether high staff turnover for Generation Y simply reflects staff moving in the early stages of their career, or is it a characteristic of the generation which will continue into the future (in which case staff turnover will incrementally increase over time)?; and whether the HE sector can afford to lose such skills and potential?

By comparison, the potential for older staff in the university to continue in employment beyond the traditional retirement ages presents a very different scenario, because turnover 
may reduce if staff opt to continue in their posts. In this university $27 \%$ of employees aged over 60 years were actually over 65, with the oldest being 73. CIPD (2015b) suggests more benefits than disadvantages to the employment of older workers. Nevertheless, there are challenges in relation to termination of contracts with employees who are employed over the age of 65 years as they can, potentially, remain working indefinitely. Traditionally older men in the university have been employed mainly full-time and older women mainly part-time, but this may evolve differently in the future as older workers desire flexible working practices that create work/ life balance. HR functions must recognise the distinctiveness of this life stage and adapt policies and procedures so as not to lose such important esoteric knowledge. It follows that there will probably be opposite trends in staff turnover for the two age groups; but will they counterbalance each other? These inter-generational differences highlight the need for HR policies in HE to adopt a life-span perspective (Hertel et al., 2013), and as the number of Generation Y employees steadily grows, managers should pay more attention to their needs and management processes should be adjusted accordingly (Meyers and Van Woerkom, 2014). Consequently, the same retention strategy cannot be applied for everybody anymore (CIPD, 2015a). Management processes should ensure that the skills of all staff are in line with the requirements of the university both strategically and operationally.

\subsection{Contractual and structural issues}

The results evidenced a relationship between staff having fixed-term contracts and research contracts, and the taking on of new staff (indicator Y), which appears to suggest that the growing tendency, identified by Metcalf et al. (2005) in 2004, to recruit to research jobs and fixed-term contracts has continued. Five academic departments had high figures for each of the three indicators (see Table 2), viz. Science Faculty Departments S.1, S.3, and S.5, and Technology Faculty Departments T.1 and T.6. 
The inference of this finding is that research staff are recruited on fixed-term contracts to support research projects that departments have won/ gained funding for, which are themselves for a fixed period. Inevitably the cycles of research project funding will vary, and so such departments will be recruiting and shedding research staff in line with project plans and funding availability; consequently, in any one year some projects will be starting, some will be continuing and some will be finishing, which will reflect in the staff turnover accordingly. Any department that has won research funding will actively look to publish as many papers as possible from such research projects, with a view to increasing its score for the REF (2015); the REF being the 5-year cycle system which assesses the quality of research in UK HE institutions. Jump (2013) argued that the REF drove the use of temporary contracts, as well as an agenda of accountability. Therefore high staff turnover can reflect a positive situation, and should not automatically be assumed to be negative, although this can obviously sometimes be the case, particularly if an organisation is facing unprecedented change. HE may face such a situation in the wake of the UK's Brexit vote (European Union Referendum Act, 2015), given that $16 \%$ of academic staff employed in the UK are from the European Union (EU) (Stokstad, 2016); which serves to reinforce the above argument for detailed analysis.

Anecdotally, there is a belief amongst some academics that the REF (2015) incentivised the recruitment or 'head-hunting' of researchers, and the gaming of the system. This is because the REF allowed the credit related to publications to sit with the author rather than the university, and therefore where a researcher moved to a new university it was the new employer rather than the old one (where the research actually took place) which gained the credit. As the movement of talent tended to be approximately two years before the REF date, the main movement period for talent for the 2014 REF was 2012/13, which was the period 
covered by this research. Therefore it may be that there was a related spike in staff turnover across the HE sector in that year. This would be the subject of further research, but the possibility should be kept in mind when considering the results. The influence of the whole issue of portability of outputs has been recognised and the rules concerning the REF and staffing may possibly change for the 2020 cycle, following the publication of the Lord Stern Review (Department for Business, Energy and Industrial Strategy, 2016), where the question of portability features prominently.

The high turnover witnessed for Generation Y employees and fixed-term research posts are obviously inter-related to some extent, given that entrants to academia tend to be recruited to fixed-term contracts in research. Being on a fixed-term contract significantly reduces satisfaction, and if nearly a quarter of academics on fixed-term contracts leave UK HE employment (Metcalf et al., 2005), then universities face a combination of challenges in relation to staff turnover and skills and talent recruitment and retention. This will only be exacerbated by uncertainties surrounding the outcomes of reforms to the Teaching Excellence Framework (TEF), with its focus on pedagogic practice (Universities UK, 2016), and Brexit (a decision the majority of university staff and students did not desire (Goodfellow, 2016)). The latter includes funding, the future recruitment of EU staff (Connolly, 2016) and retaining UK-based EU staff who may not wish to remain in a non-EU country (Matthews and Morgan, 2016). It follows that, whilst universities naturally compete with one another for the best staff, the loss of personnel across the whole sector needs to be addressed, if this leads to skills shortages in key areas.

\subsection{Intelligence about staff}


Whilst this research has provided in-depth analysis for a large UK university, the approach and lessons are critical to many, if not most large organisations in any sector across the world. This is because there is a need for HR functions to evaluate the performance of human capital, of which turnover is only one aspect, as highlighted by Hesketh (2014). He found that the necessary systems were 'largely absent'; something subsequently endorsed by CIPD (2015c) which stressed the related challenges involved as HR is expected to become more business focussed. There should be greater attention on well-thought determinants for young staff retention, with management practices customised to this end. Whilst this may be the emphasis, the wider applicability of such management processes to all age groups must also be taken into account.

\section{Conclusions}

It has been demonstrated that focusing on headline staff turnover rates for a large organisation, such as a university, can mask wide variations for individual departments. There are many intertwined contributory influences and dynamics within the specific context of HE's growing age-diverse knowledge workforce. These include differential and opposing staff retention patterns at either end of the age spectrum, gender, the levels of research and contributions to the REF (2015), the usage of fixed-term contracts, and the type of university. Traditionally, scrutiny of turnover has been reactive, but a proactive approach needs to be adopted to underpin a university's HR management. Whilst universities and organisations should benchmark themselves against their peers, it is imperative that they also analyse local data, to reflect local context. Understanding the internal and external staff dynamics is essential to meet strategic aims and objectives, particularly in anticipation of the uncertain impacts of: the Lord Stern Review (Department for Business, Energy and Industrial Strategy, 2016) on the REF; the Teaching Excellence Framework (TEF) (Universities UK, 2016); and 
Brexit (European Union Referendum Act, 2015); and should enable a university to pinpoint where local action might be necessary, although some issues would benefit from sector-wide consideration and action, e.g. how to retain talented staff that are coming to the end of fixedterm contracts.

Such an approach should similarly help large organisations to evolve their management and HR policies and practices to meet future staffing challenges (for example, addressing the needs of the increasing numbers of Generation Y staff and dealing with staff working beyond retirement age), and better manage their recruitment budget, given that high staff turnover directly impacts on this. Whilst this research has looked in detail at a UK university, the issues of staff management in times of uncertainty are common across all large organisations across the world, albeit with variations between countries and sectors. Therefore, it is reasonable to infer that the approach and findings of the research are critical to many, if not most large organisations in the UK and internationally.

\section{References}

Ackers, L. and Gill, B. (2005), “Attracting and retaining 'Early Career' researchers in English Higher Education Institutions”, Innovation: The European Journal of Social Science Research, Vol.18 No.3, pp.277-299 doi.org/10.1080/13511610500186649

Age UK (2015), "Default Retirement Age”, available at: http://www.ageuk.org.uk/work-andlearning/discrimination-and-rights/default-retirement-age---frequently-asked-questions/ (accessed 12 December 2016)

Allen, D., Bryant, D. and Vardaman, J. (2010), "Retaining talent: replacing misconceptions with evidence based strategies", Academy of Management Perspectives, Vol.24, No.2, pp.4864. 
Armstrong, C. (2008), "What is a University in the UK?", available at:

http://www.jobs.ac.uk/careers-advice/working-in-higher-education/1135/what-is-a-universityin-the-uk (accessed 12 December 2016)

Bratton, J. and Gold, J. (2017), "Human Resource Management: Theory and Practice", London: Palgrave.

Breakwell, G. and Tytherleigh, M. (2010), "University leaders and university performance in the United Kingdom: is it 'who' leads, or 'where' they lead that matters most?", Higher Education, Vol.60, pp.491-506

Brown, E., Thomas, N. and Bosselman, R. (2015), “Are they leaving or staying: A qualitative analysis of turnover issues for Generation Y hospitality employees with a hospitality education”, International Journal of Hospitality Management Vol.46, pp.130-137 doi:10.1016/j.ijhm.2015.01.011

Cardy, L. and Lengnick-Hall, M. (2011), "Will they stay or will they go? exploring a customer-oriented approach to employee retention", Journal of Business and Psychology Vol.26, pp.213-217

Chartered Institute of Personnel and Development (2015a), "Resourcing and Talent Planning", available at: http://www.cipd.co.uk/binaries/resourcing-talent-planning_2015.pdf (accessed 12 December 2016)

Chartered Institute of Personnel and Development (2015b), "Managing an age-diverse workforce: What employers need to know", available at: http://www.cipd.co.uk/binaries/managing-an-age-diverse-workforce_2015-what-employersneed-to-know.pdf (accessed 12 December 2016)

Chartered Institute of Personnel and Development (2015c), "Views of Our Profession", in $H R$ Outlook, available at: http://www.cipd.co.uk/hr-resources/survey-reports/hr-outlook-winter2014-15-views-profession.aspx (accessed 12 December 2016) 
Chartered Institute of Personnel and Development (2016), "Who We Are”, available at: http://www.cipd.co.uk/cipd-hr-profession/about-us/ (accessed 12 December 2016)

Collings, D. (2015), “Talent management and human resource development”, paper presented at 16th International Conference on Human Resource Development Research and Practice across Europe, July 3-5, University of Cork, Ireland

De Romrée, H., Fecheyr-Lippens B. and Schaninger, B. (2016), "People analytics reveals three things HR may be getting wrong”, in McKinsey Quarterly article, July, available at: http://www.mckinsey.com/business-functions/organization/our-insights/people-analyticsreveals-three-things-hr-may-be-getting-wrong (accessed 12 December 2016)

Connolly, C. (2016), "What now for UK academia? Twelve academics on Brexit", available at: https://womenareboring.wordpress.com/2016/06/27/what-now-for-uk-academia-twelveacademics-on-brexit/ (accessed 12 December 2016)

Cotton, J. and Tuttle, J. (1986), "Employee turnover: A meta-analysis and review with implications for research", Academy of Management Review Vol.55 No.1, pp.55-70 Department for Business, Energy and Industrial Strategy (2016), “Building on Success and Learning from Experience: An Independent Review of the Research Excellence Framework (Lord Stern Review)", available at:

https://www.gov.uk/government/uploads/system/uploads/attachment_data/file/541338/ind-169-ref-stern-review.pdf (accessed 12 December 2016)

Department for Work and Pensions and ACAS (2014), "Managing Attendance and Employee Turnover", available at: http://www.acas.org.uk/media/pdf/q/k/Managing-attendance-andemployee-turnover-advisory-booklet.pdf (accessed 12 December 2016) DLA Piper (2015), “HR Benchmarker Workforce Performance Indicators: Higher Education Report - 2014”. 
Ehrenberg, R., Rizzo, M. and Jackson, G. (2006), "Who bears the growing cost of science at universities?", Cornell Higher Education Research Institute Working Paper 35. European Union Referendum Act 2015, available at:

http://www.legislation.gov.uk/ukpga/2015/36/pdfs/ukpga_20150036_en.pdf (accessed 12 December 2016)

Gandy, R. (2009), “Demonstrating churn diagrammatically”, paper presented at 32nd Institute for Small Business \& Entrepreneurship Conference, November 3-6, Liverpool Gates, S. (2004), “Measuring More than Efficiency”, Research Report no. R-1356-04-RR. New York: Conference Board.

Glebbeek, A.C., and Bax, E.H. (2004), “Is high employee turnover really harmful: an empirical test using company records", Academy of Management Journal, Vol. 47, No.2, pp. 277-286.

Goodfellow, J. (2016), “Brexit: What will it mean for universities, students and academics?" The Telegraph, 1 July, available at: http://www.telegraph.co.uk/education/2016/07/01/brexitwhat-will-it-mean-for-universities-students-and-academics/ (accessed 12 December 2016) Groysberg, B. (2010), Chasing Stars. [Electronic Resource]: The Myth Of Talent And The Portability Of Performance, Princeton, N.J. ; Woodstock : Princeton University Press Hancock, J., Allen, G., Bosco, F., McDaniel, K. and Pierce, C. (2013), "Meta-analytic review of employee turnover as a predictor of firm performance”, Journal of Management Vol.39 No.3, pp.573-603 Hertel, G., Heijden, B., Annet, H. and Deller, J. (2013), "Facilitating age diversity in organizations - part I: challenging popular misbeliefs", Journal of Managerial Psychology Vol.28 No.7/8, pp.729-740

Hesketh, A. (2014), "Managing the value of your talent - A new framework for human capital measurement", available at: 
http://www.cimaglobal.com/Documents/Thought_leadership_docs/Organisational\%20manage ment/Managing-value-of-talent.pdf (accessed 12 December 2016)

Higher Education Information Database for Institutions (2015), "Summary guide to all HESA data", available at: http://www.heidi.ac.uk/dox/heidi_summary_HESA.pdf (accessed 12 December 2016)

Higher Education Statistical Agency (2010), "Resources of Higher Education Institutions 2008/09 - Table 5: Staff (excluding atypical) by activity, mode of employment, age and gender", available at:

https://www.hesa.ac.uk/index.php?option=com_content $\&$ view=article\&id=3432 $($ accessed 11 September 2015)

Higher Education Statistical Agency (2014), available at: https://www.hesa.ac.uk (accessed 12 December 2016)

Higher Education Statistical Agency (2015), “FTE vs FPE”, available at: https://www.hesa.ac.uk/collection/c15025/fte_vs_fpe/.html/.html/ (accessed 12 December 2016)

Jump, P. (2013), "Cardiff baker's dozen: for expiry date, check the REF”, Times Higher Education, 27 June, pp.6-8

Lawrence, J., Celis, S., Hee-Sun, K., Ketchen-Lipson, S. and Tong, X. (2013), “To stay or not to stay: retention of Asian international faculty in STEM fields", Higher Education Vol.67, pp.511-531

London Business School (2014), "News and Events: 90\% of Gen Y spends less than five years with an employer", available at: https://www.london.edu/news-and-events/news/90-ofgen-y-spends-less-than-five-years-with-an-employer\#.Vlh1btLhDwc (accessed 12 December 2016) 
Mahroum, S. (1999), "Patterns of Academic Inflow into the Higher Education System of the United Kingdom", Higher Education in Europe Vol.24 No.1, pp.119-129

Marginson, S. (2013), “The impossibility of capitalist markets in higher education”, Journal of Education Policy Vol.28 No.3, pp.353-370. doi: 10.1080/02680939.2012.747109.

Matthews, D. and Morgan, J. (2016), "Brexit: growing numbers of UK academics face EU funding worries", The Times Higher Education, 5 July, available at:

https://www.timeshighereducation.com/news/brexit-growing-numbers-uk-academics-face-eufunding-worries (accessed 12 December 2016)

Metcalf, H., Rolfe, H., Stevens, P. and Weale, M. (2005), "Recruitment and Retention of Academic Staff in Higher Education”, National Institute of Economic and Social Research. ISBN 1844785238

Meyers, M. and Van Woerkom, M. (2014), “The influence of underlying philosophies on talent management: Theory, implications for practice, and research agenda", Journal of World Business, Vol.49 No.2, pp.192-203

Raju, S., Suresh, A., Chand, R. and Chauhan, S. (2015), "Pattern and trend in labour use in Indian agriculture: An analysis across major crops and states", Economic Affairs, Vol.60 No.1, pp.99-108. doi: 10.5958/0976-4666.2015.00014.5

Ref2020 Consulting (2015), available at: http://www.ref2020.co.uk/ (accessed 12 December 2016)

Research Excellence Framework (2015), available at: http://www.ref.ac.uk/about/ (accessed 12 December 2016)

Schroer, W. (2015), “Generations X,Y, Z and the Others", The Social Librarian, available at: http://www.socialmarketing.org/newsletter/features/generation3.htm. (accessed 12 December 2016) 
Siebert, W.S. and Zubanov, N. (2009). "Searching for the optimal level of employee turnover: a study of a large U.K. retail organization". Academy of Management Journal, Vol. 52, No. 2, pp.294-313.

Stokstad, E. (2016), “Uncertainty reigns in Brexit Britain”, Science, Vol.353 No.6298, pp.437. doi: 10.1126/science.353.6298.437

Sutherland, J. (1998), "Workforce reduction strategies: an empirical examination of the options”, Employee Relations, Vol.20 No.2, pp.148-163. doi: 10.1108/01425459810211313 UNESCO (1998), Benchmarking in Higher Education: A study conducted by the Commonwealth Higher Education Management Service. ED98/WS/12. United Nations Educational, Scientific and Cultural Organization, Paris Universities and Colleges Employers Association (2014), available at: http://www.ucea.ac.uk/en/about/index.cfm (accessed 12 December 2016) Universities UK (2016), "Universities UK response to the Teaching Excellence Framework technical consultation for year two", available at: http://www.universitiesuk.ac.uk/policyand-analysis/reports/Documents/2016/response-to-tef-technical-consultation.pdf (accessed 12 December 2016)

Veleso, E., Silva, R., Dutra, J., Fischer, A. and Trevisan, L. (2014), “Talent retention strategies in different organizational contexts and intention of talents to remain in the company", Journal on Innovation and Sustainability Vol.5 No.1, pp.49-61

Welfare Rights on the Net (2015), "Benefits Guides: Working Tax Credits”, available at: http://www.welfarerights.net/benefits-guides/Working-Tax-Credits (accessed 12 December 2016)

Workforce Employment Relations Study (2013), “The 2011 Workplace Employment Relations Study: First findings report", available at: 
https://www.gov.uk/government/uploads/system/uploads/attachment_data/file/336651/bis-141008-WERS-first-findings-report-fourth-edition-july-2014.pdf (accessed 12 December 2016) 